\title{
Effects of Cyclodextrins on Fading of Azo Dyes with Sodium Sulfite
}

\author{
Chizuyo Katsumata and Kazuyoshi Seguchi \\ Faculty of Human Environmental Sciences, Mukogawa Women's University \\ (6-46 Ikebiraki, Nishinomiya-shi 663-8558)
}

\begin{abstract}
Effects of cyclodextrins (CyD) on fading of various azo dyes such as 1-arylazo-2naphthols, 1-arylazo-4-naphthols, and 2-arylazo-1-naphthols with sodium sulfite at $30^{\circ} \mathrm{C}$ were investigated. Fading was found to occur as a result of adding of sulfite to a conjugate enone moiety (Caddition) or to a conjugate iminone moiety ( $\mathrm{N}$-addition) in the hydrazone tautomer. In the case of $\mathrm{C}$ addition mainly conducted for 1-arylazonaphthols, the addition of $\beta$-CyD lessened the rate of fading through formation of an inclusion complex at the naphthol site of the dye. $\alpha$-CyD had only limited effect on the fading rate since the cavity was too small to permit dye inclusion. Inclusion complexes were confirmed by vis-spectral change in the dyes subsequent to the addition of CyD. $\alpha$-CyD caused remarkable retardation of fading for 2-arylazo-1-naphthols following $\mathrm{N}$-addition. Inclusion of the dyes at the aryl site that would promote complexation was considered as explanation for this. $\beta$-CyD acted as an efficient retarding agent in the $\mathrm{N}$-addition process. Retarding efficiency of fading due to CyD is discussed based on substituent effects, disposition of dyes in CyD cavities, reaction sites of the dyes, and the binding constant $(K a)$.
\end{abstract}

Key words : cyclodextrin, binding constant, fading, azo dye, sodium sulfite

\section{Introduction}

Cyclodextrins (CyD) are cyclic oligomers consisting of $\alpha$-D- $(+)$-glucopyranose residues, and include various compounds specifically into their relatively hydrophobic cavity ${ }^{1}$. In particular, since Cramer's systematic publication relating to azo dye-CyD complex formation ${ }^{2}$, the complexes have been characterized by many researchers by means of X-ray diffraction ${ }^{3 / 25}$, NMR spectroscopy ${ }^{6,7)}$, temperature jump ${ }^{2,8), 10)}$, pressure jump ${ }^{11)}, \mathrm{UV}, \mathrm{CD}$, and fluorescence spectrophotometries ${ }^{2), 10) \sim 13)}$. However, the majority of published studies on the azo-CyD complexes have been largely concerned on stability of the complex, and there are few reports focussing on reactions of azo dyes in the presence of CyD. In this respect, Sanchez et. al. have recently reported the effect of $\beta-\mathrm{CyD}$ on thermal $Z-E$ isomerization of some azo dyes ${ }^{14)}$.

Corresponding author: Chizuyo KATSUMATA
In order to acquire more marked CyD-effects such as rate-enhancement, rate-retardation, and high regioselectivities, bimolecular reaction systems are doubtlessly better choice. In the previous papers ${ }^{15), 16)}$, we have reported that azo dyes clearly fade with sodium sulfite through an addition of sodium sulfite to a conjugate enone moiety $(C=C$ $\mathrm{C}=\mathrm{O})$ [C-addition] or a conjugate iminone moiety $(\mathrm{N}=\mathrm{C}-\mathrm{C}=\mathrm{O})$ [ $\mathrm{N}$-addition] in hydrozone tautomer of the dyes. Upon the addition of $\mathrm{CyD}$ to this reaction system, the fading of the dyes must be retarded, depending on tightness of the $\mathrm{CyD}$ complexes as well as on the attacking sites of sulfite. We describe herein our results as to the fading of a variety of azo dyes with sodium sulfite in the presence of $\alpha$ - and $\beta$-CyDs.

\section{Experimentals}

\subsection{Instruments and Materials}

The chemical structures of azo dyes used were shown in Fig.1. These dyes were prepared from 


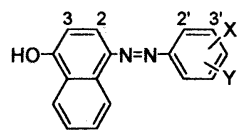

Dye-1: $X=4^{\prime} \cdot \mathrm{SO}_{3} \mathrm{Na}, \mathrm{Y}=\mathrm{H}$ Dye-2: $X=2^{2}-\mathrm{SO}_{3} \mathrm{Na}, Y=\mathrm{H}$ Dye-3: $X=2 \cdot-\mathrm{CH}_{3}, Y=4^{\prime}-\mathrm{SO}_{3} \mathrm{Na}$

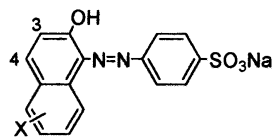

Dye-5: $X=H$

Dye-6: $X=6-\mathrm{SO}_{3} \mathrm{Na}$ Dye-7: $X=8-\mathrm{SO}_{3} \mathrm{Na}$

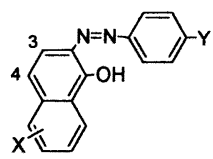

Dye-9: $\quad X=4-\mathrm{SO}_{3} \mathrm{Na}, \mathrm{Y}=\mathrm{H}$ Dye-10: $X=4-\mathrm{SO}_{3} \mathrm{Na}, Y=\mathrm{NO}_{2}$ Dye-11: $X=4-\mathrm{SO}_{3} \mathrm{Na}, Y=\mathrm{CH}_{3}$ Dye-12: $X=4-\mathrm{SO}_{3} \mathrm{Na}, Y=\mathrm{SO}_{3} \mathrm{Na}$ Dye-13: $X=5-\mathrm{SO}_{3} \mathrm{Na}, \mathrm{Y}=\mathrm{SO}_{3} \mathrm{Na}$

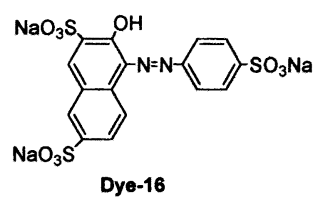

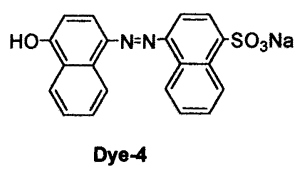

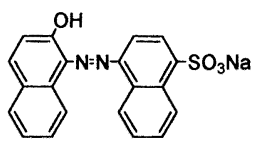

Dye-8

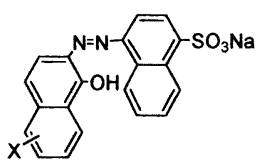

Dye-14: $X=4-\mathrm{SO}_{3} \mathrm{Na}$ Dye-15: $X=5-\mathrm{SO}_{3} \mathrm{Na}$

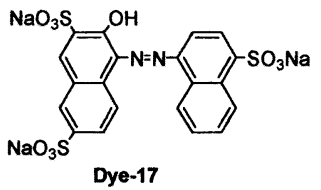

Fig.1 Structures of Used Dyes.

the coupling reactions of naphthol derivatives with diazonium salts of aniline or 1-naphthylamine derivatives according to conventional procedures ${ }^{17)}$, and purified either by recrystallization from water or ethanol, or in the case of the more soluble dyes, by precipitation with sodium acetate. The purity of the dyes was confirmed by paper chromatography (developer ; butanol : pyridine : water $=6: 3: 4) . \alpha$ - and $\beta$-CyDs were purchased from Nacalai Tesque and used without further purifications. ${ }^{1} \mathrm{H}$ and ${ }^{13} \mathrm{C}-\mathrm{NMR}$ spectra were recorded on a Hitachi R-1900 spectrometer. UV-vis spectra were conducted on a Shimadzu UV-260 spectrophotometer.

\section{$2 \cdot 2$ Binding Constant}

The binding constants $(K a)$ for azo dye-CyD complexes were determined spectrophotometrically at $20^{\circ} \mathrm{C}$. The spectral changes of azo dyes $(1.25$ $\left.\times 10^{-5}-5.0 \times 10^{-5} \mathrm{M}\right)$ in the absence and the presence of $\mathrm{CyD}\left(0-1.0 \times 10^{-2} \mathrm{M}\right)$ were measured at $\mathrm{pH}$ 7.0. The $K a$ values were calculated according to the following equation ${ }^{2)}$.

$$
[\mathrm{D}][\mathrm{CyD}] / \Delta A=1 /\left(K a \Delta \varepsilon_{c}\right)+[\mathrm{CyD}] / \Delta \varepsilon_{c}
$$

where [D] is the total concentration of a dye, [CyD] is the total concentration of $\mathrm{CyD}, \Delta \varepsilon_{c}$ is the difference between the molar absorption coefficients for free and complexed dyes and $\Delta A$ is the change of absorbance of the dye on the addition of CyD.

\subsection{Fading Rate Constants}

A solution of sodium sulfite was added to a dye solution adjusted at $\mathrm{pH} 7.0$ with phosphate buffer in the absence and the presence of $\mathrm{CyD}$. Concentrations of these solutions were $1.25-2.0$ $\times 10^{-5} \mathrm{M}$ for a dye, $0-2.0 \times 10^{-3} \mathrm{M}$ for $\mathrm{CyD}$, and $1.5 \times 10^{-3}-5.0 \times 10^{-2} \mathrm{M}$ for sodium sulfite. The reaction mixture was transferred into a quartz cell, immersed in the thermostatted bath maintaining at $30 \pm 0.5^{\circ} \mathrm{C}$, and the fading reaction was pursued spectrophotometrically at appropriate intervals. The second-order rate constants of fading $\left(k_{0}\right)$ were obtained by application of pseudo-first-order kinetics to the observed spectral changes.

\subsection{Fading Product}

After completion of a fading reaction with sodium sulfite in a phosphate buffer solution, tetraphenylphosphonium bromide (TPPB) was added to the reaction solution and the fading product was extracted with dichloromethane as an ion-complex of TPPB. The extract was concentrated and dried under vacuum. The ${ }^{1} \mathrm{H}-\mathrm{NMR}$ spectrum of the oily residue was measured in $\mathrm{CDCl}_{3}$. The chemical shifts were given in $\delta$ values using TMS as an internal standard. ${ }^{1} \mathrm{H}-\mathrm{NMR}$ spectra of the fading products were also obtained directly from the fading reaction in a NMR sample-tube using $\mathrm{D}_{2} \mathrm{O}$ as a solvent.

The reaction solutions of Dye-11, 14, 15, and 17 were subjected to paper chromatography after decolorization. The spots of arylamines were identified by successive spray of solutions of hydrochloric acid, sodium nitrite, and NW-acid (1naphthol-4-sulfonic acid).

\section{Results and Discussion}

\section{$3 \cdot 1$ Fading Product}

As reported previously, fading of azo dyes with sodium sulfite occurred through nucleophilic addition of sodium sulfite to the hydrazone tautomer of the dyes and could be classified into two types of reactions, $\mathrm{C}$-addition and $\mathrm{N}$-addition, based on UV-vis spectral behavior and the reaction sites of the dyes, which depended strongly 


\section{C-Addition}

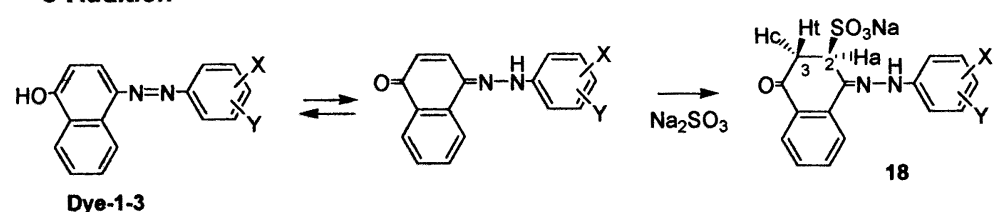

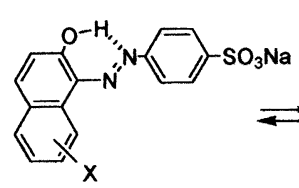

Dye-5-7

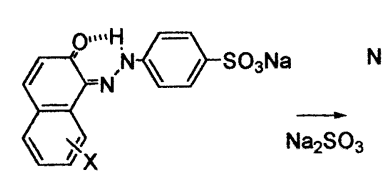

$\overrightarrow{\mathrm{Na}_{2} \mathrm{SO}_{3}}$

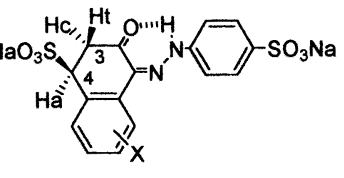

19

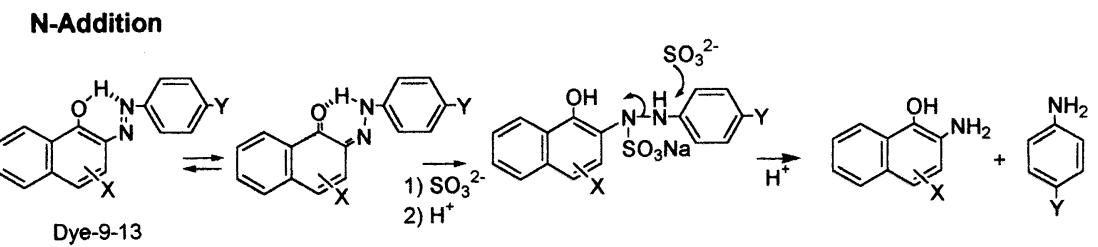

Scheme 1 Fading Mechanism.

on the structures of dyes ${ }^{16)}$. As the mechanisms were shown in Scheme 1, the fading products in Caddition are Michael adducts of sodium sulfite to a conjugate enone moiety in the hydrazone tautomer. However, C-addition is inhibited in steric origin when a bulky substituent such as a sulfo group lies near the reaction site, or when the hydroazone tautomer of azo dyes cannot have a conjugate enone moiety. In these cases, sulfite initially adds to $\alpha$-nitrogen of the hydrazone tautomer of the dye (N-addition), followed by reduction of azo group to form two different amines, although $\mathrm{N}$-addition shows much lower reactivity than $\mathrm{C}$-addition.

The fading rate constants $\left(k_{0}\right)$ of azo dyes employed here with sodium sulfite at $30^{\circ} \mathrm{C}$ were obtained from spectrophotometric behavior and listed in Table 1. These rate constants are classified distictly into two groups; a group of relatively high reactivities $\left(289-1030 \times 10^{-4}\right.$ $\mathrm{M}^{-1} \mathrm{~S}^{-1}$ ) as seen for Dye-1-8 and a group of low reactivities $\left(2.76-40.3 \times 10^{-4} \mathrm{M}^{-1} \mathrm{~s}^{-1}\right)$ as seen for Dye-9-17. Although spectral changes observed for these dyes by sodium sulfite were not shown here, isosbestic points in the visible region (near 405$468 \mathrm{~nm}$ ) were observed for the former group with a decrease in absorbance of dye at $\lambda_{\max }$, and conversely, no isosbestic point in the visible region was observed for the latter group. These spectral characteristics and the reactivities are in good agreements with those of $\mathrm{C}$-addition and $\mathrm{N}$ addition, respectively as reported previously ${ }^{15) .16)}$.

In order to confirm the structure of fading products of Dye-2-4 and 8 with sodium sulfite, ${ }^{1} \mathrm{H}$ and ${ }^{13} \mathrm{C}$-NMR spectra in $\mathrm{D}_{2} \mathrm{O}$ were measured. The NMR data are shown in Table 2. In the ${ }^{1} \mathrm{H}-\mathrm{NMR}$ spectra two proton signals appeared at $\delta 3.0-4.9$ with small coupling constant $(J=0.5-0.8 \mathrm{~Hz})$. Furthermore, the ${ }^{1} \mathrm{H}$-NMR spectra of the products as ТPPB ion-complexes in $\mathrm{CDCl}_{3}$ showed three proton signals at $\delta 2.2-4.9$ coupling with each other (ABX system) and one singlet at $\delta 9.9-14.7$. The spectral difference in $\mathrm{D}_{2} \mathrm{O}$ and $\mathrm{CDCl}_{3}$ indicates that an amino proton and a trans-proton to a sulfo group were deuterated in $\mathrm{D}_{2} \mathrm{O}$. From comparison with previously reported data for Dye-1, and 5$7^{15) .16)}$, the fading products of Dye-2-4 and 8 were determined as $\mathrm{C}$-adducts of sulfite (Michael adducts, 18 for 1-arylazo-4-naphthols and $\mathbf{1 9}$ for 1arylazo-2-naphthols) as exemplified in Scheme 1. The ${ }^{13} \mathrm{C}$-NMR spectra of the fading products of Dye-2, 3, and 8 in $\mathrm{D}_{2} \mathrm{O}$, in which signals due to a methine carbon and a carbonyl carbon appeared at $\delta 55.7-60.0$ and 196-199 respectively, support these structures. Since the fading product of Dye-4 was hardly soluble in $\mathrm{D}_{2} \mathrm{O}$, the ${ }^{13} \mathrm{C}-\mathrm{NMR}$ spectrum was measured in $\mathrm{CDCl}_{3}$ as an ion-complex with TPPB.

In contrast, the ${ }^{1} \mathrm{H}-\mathrm{NMR}$ spectra of fading 
Table 1 Fading Rate Constant $\left(k_{0}\right)$ of Dyes with Sodium Sulfite at $30^{\circ} \mathrm{C}$ in the Absence of CyD, Binding Constant $(K a)$ of CyD with Dyes, and CyD-Effect on Fading Rates.

\begin{tabular}{|c|c|c|c|c|c|c|c|c|c|}
\hline \multirow{3}{*}{ Dye } & \multirow{3}{*}{$\begin{array}{l}\text { Rate constant }\left(k_{0}\right)^{\mathrm{a})} \\
\qquad\left(10^{-4} \mathrm{M}^{-1} \mathrm{~s}^{-1}\right)\end{array}$} & \multicolumn{4}{|c|}{$\alpha-\mathrm{CyD}$} & \multicolumn{4}{|c|}{$\beta-\mathrm{CyD}$} \\
\hline & & \multirow{2}{*}{$\begin{array}{l}K a \\
\left(\mathrm{M}^{-1}\right)\end{array}$} & & \multirow{2}{*}{$\begin{array}{c}k_{C y D} / k_{0} \\
50^{\mathrm{b})}\end{array}$} & \multirow{2}{*}{\multicolumn{2}{|c|}{ 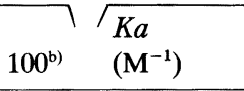 }} & \multicolumn{3}{|c|}{$k_{C y D} / k_{0}$} \\
\hline & & & $20^{\mathrm{b})}$ & & & & $20^{c)}$ & $50^{\mathrm{c})}$ & $100^{c)}$ \\
\hline \multicolumn{10}{|c|}{ C-addition } \\
\hline 1 & 891 & $456 \pm 41$ & 0.94 & 0.93 & 0.89 & $252 \pm 27$ & 0.81 & 0.65 & 0.54 \\
\hline 2 & 449 & - & 0.99 & 1.00 & 0.98 & $191 \pm 4$ & 0.94 & 0.79 & 0.68 \\
\hline 3 & 740 & - & 0.98 & 0.95 & 1.02 & $1180 \pm 70$ & 0.46 & 0.28 & 0.20 \\
\hline 4 & 1030 & - & 1.02 & 1.01 & 1.06 & $2890 \pm 340$ & 0.70 & 0.51 & 0.39 \\
\hline 5 & 416 & - & 1.00 & 1.01 & 1.05 & $1250 \pm 220$ & 0.86 & 0.75 & 0.71 \\
\hline 6 & 289 & - & 1.07 & 1.16 & 1.16 & $608 \pm 36$ & 1.11 & 1.04 & 1.01 \\
\hline 7 & 306 & - & 1.07 & 1.02 & 1.04 & $75 \pm 11$ & 0.96 & 0.92 & 0.89 \\
\hline 8 & 402 & - & 1.02 & 1.06 & 1.06 & $1370 \pm 110$ & 0.96 & 0.81 & 0.65 \\
\hline \multicolumn{10}{|c|}{$\mathrm{N}$-addition } \\
\hline 9 & 4.68 & $2570 \pm 130$ & 0.53 & 0.31 & 0.20 & $1920 \pm 120$ & 0.65 & 0.46 & 0.31 \\
\hline 10 & 40.3 & $3940 \pm 190$ & 0.82 & 0.76 & 0.72 & $3240 \pm 190$ & 0.65 & 0.61 & 0.58 \\
\hline 11 & 2.76 & $4860 \pm 240$ & 0.45 & 0.21 & 0.13 & $2000 \pm 100$ & 0.52 & 0.34 & 0.24 \\
\hline 12 & 9.67 & $1060 \pm 60$ & 0.81 & 0.61 & 0.42 & $1650 \pm 80$ & 0.90 & 0.70 & 0.52 \\
\hline 13 & 6.30 & $909 \pm 91$ & 0.69 & 0.51 & 0.35 & $1450 \pm 60$ & 0.54 & 0.34 & 0.22 \\
\hline 14 & 21.2 & - & 1.02 & 1.08 & 1.14 & $1150 \pm 60$ & 0.56 & 0.34 & 0.20 \\
\hline 15 & 16.3 & - & 1.09 & 1.11 & 1.03 & $2560 \pm 130$ & 0.39 & 0.21 & 0.12 \\
\hline 16 & 16.0 & - & 1.04 & 1.08 & 1.10 & $285 \pm 17$ & 0.79 & 0.72 & 0.66 \\
\hline 17 & 37.3 & - & 0.99 & 1.00 & 1.01 & $255 \pm 23$ & 0.84 & 0.78 & 0.66 \\
\hline
\end{tabular}

a) Average of duplicate runs. The error in these values is estimated to be $6 \%$. b) Molar ratio of $\alpha$-CyD and a dye.

c) Molar ratio of $\beta-\mathrm{CyD}$ and a dye.

products of Dye-11, 14, 15, and 17 with sodium sulfite in $\mathrm{D}_{2} \mathrm{O}$ did not show appreciable signals in the aliphatic regions except for methyl protons for Dye-11. Paper chromatogram of fading products of Dye-14, 15, and 17 gave same spot, the color of which changed from pale yellow to brilliant red by spraying a NW-acid solution $(\mathrm{Rf}=0.46)$. The spot was identified as naphthionic acid by comparison with the authentic sample. The main fading product for Dye-11 was $p$-toluidine from ${ }^{1} \mathrm{H}-\mathrm{NMR}$ spectrum of the dichloromethane extract of the fading solution. Naphthionic acid for Dye-14, 15, and $\mathbf{1 7}$ and $p$-toluidine for Dye-11 were obtained in the yields of $85-98 \%$ and $99 \%$, respectively (based on peak integration of ${ }^{1} \mathrm{H}-\mathrm{NMR}$ spectra in $\mathrm{D}_{2} \mathrm{O}$ ). As reported previously for Dye-9, 10, 12, 13, and 16 , the reduction of azo dyes to aromatic amines is characteristic for $\mathrm{N}$-addition.

\section{$3 \cdot 2$ Effect of $\mathbf{C y D}$}

$3 \cdot 2 \cdot 1 \quad$ C-addition type

The effects of CyD on fading rates of Dye-1-8 with sodium sulfite are shown in Table 1, together with the binding constants $(K a)$ for the inclusion complex. The effects of $\mathrm{CyD}$ are expressed as the rate-ratios of $k_{C y D}$ (in the presence of $\mathrm{CyD}$ ) and $k_{0}$ (in the absence of $\mathrm{CyD}$ ). It should be noted that the fading of these dyes proceeds through Caddition of sulfite to the enone moiety at the naphthol side as mentioned above.

The gradual addition of $\beta$-CyD caused retardation of the fading significantly except for Dye-6. In contrast, $\alpha$-CyD had slight effects on the rates of the fading except for Dye-1. These contrasting results can be primarily explained from inclusion of the dye at the naphthol side in CyD cavity. As well-known, $\beta$-CyD can form inclusion complexes with the naphthol-based dyes, but $\alpha$-CyD cannot include the naphthol side of the dyes because of smaller diameter of its cavity ${ }^{2,9,11,12)}$. The facts quite meet with our observed results as to spectral changes of the dyes in the visible regions by the addition of CyD (Table 3). Namely, upon the addition of $\beta$-CyD, shifts of $\lambda_{\max }$ of the dye and/or a decrease in the absorption at $\lambda_{\max }$ were observed to allow the determination of the $K a$ values, but $\alpha$ CyD did not cause appreciable spectral changes except for Dye-1. The spectral changes of Dye-1 by $\alpha$-CyD are fully anticipated from inclusion not 
Table 2 Selective ${ }^{1} \mathrm{H}$ and ${ }^{13} \mathrm{C}-\mathrm{NMR}$ Data of Fading Products.

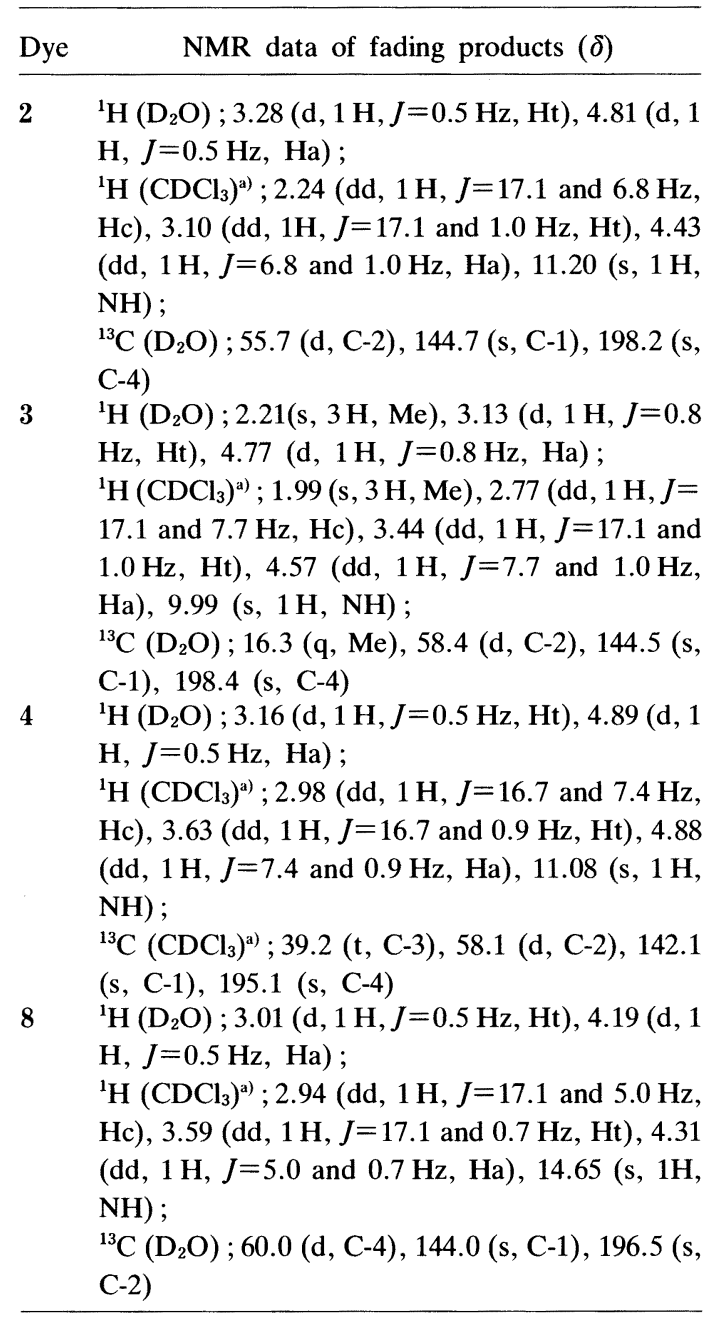

a) Ion complex with TPPB.

at the naphthol side but at the hydrophobic benzene side.

When the inclusion with $\beta$-CyD at the naphthol side occurs, the reaction site (C-3) of 1-naphtholbased dyes (Dye-1-4) for sulfite is on the wall side of $\beta$-CyD in the complex, but the reaction site (C4) of 2-naphthol-based dyes (Dye-5-8) is on the open side of $\beta$-CyD as illustrated in Fig.2. Therefore, $\beta$-CyD will protect 1-naphthol-based dyes more effectively from attack of sulfite than 2naphthol-based dyes. These are typical cases; remarkable retardation for Dye-3 and 4, and less effective retardation for Dye-5 and 8 than expected from their large $K a$ values. Furthermore,
Table 3 Spectral Characteristics in the Absence and the Presence of CyD.

\begin{tabular}{|c|c|c|c|c|c|}
\hline \multirow[b]{2}{*}{ Dye } & \multirow[b]{2}{*}{$\lambda_{\max }(\mathrm{nm})^{\mathrm{a})}$} & \multicolumn{2}{|c|}{$\alpha-\mathrm{CyD}$} & \multicolumn{2}{|c|}{$\beta$-CyD } \\
\hline & & $\lambda_{\max }(\mathrm{nm})^{\mathrm{b})}$ & $\mathrm{A}_{\mathrm{cyD}} / \mathrm{A}_{0}{ }^{\mathrm{b}), \mathrm{c}}$ & $\lambda_{\max }(\mathrm{nm})^{\mathrm{b})}$ & $A_{c y D} / A_{0}^{b), c)}$ \\
\hline 1 & 473 & 476 & 0.95 & 477 & 0.77 \\
\hline 2 & 468 & 468 & 1.02 & 472 & 0.97 \\
\hline 3 & 471 & 471 & 0.99 & 469 & 0.74 \\
\hline 4 & 482 & 482 & 1.01 & 481 & 0.82 \\
\hline 5 & 482 & 482 & 0.99 & 484 & 0.86 \\
\hline 6 & 479 & 479 & 1.00 & 482 & 0.90 \\
\hline 7 & 476 & 476 & 0.99 & 477 & 0.98 \\
\hline 8 & 503 & 503 & 1.02 & 507 & 1.00 \\
\hline 9 & 489 & 497 & 0.88 & 491 & 0.88 \\
\hline 10 & 496 & 501 & 0.94 & 498 & 0.93 \\
\hline 11 & 496 & 505 & 0.93 & 498 & 0.86 \\
\hline 12 & 489 & 493 & 0.87 & 491 & 0.88 \\
\hline 13 & 501 & 504 & 0.89 & 500 & 0.84 \\
\hline 14 & 513 & 513 & 1.01 & 516 & 0.93 \\
\hline 15 & 523 & 523 & 1.00 & 523 & 0.89 \\
\hline 16 & 486 & 486 & 1.01 & 489 & 0.95 \\
\hline 17 & 519 & 519 & 1.01 & 520 & 0.96 \\
\hline
\end{tabular}

a) In the absence of $\mathrm{CyD}$. b) At $[\mathrm{CyD}] /[\mathrm{Dye}]=100$.

c) Ratio of absorbance at $\lambda_{\max }$ in the presence $\left(\mathrm{A}_{\mathrm{cyD}}\right)$ and the absence of $\mathrm{CyD}\left(\mathrm{A}_{0}\right)$.

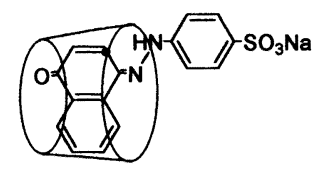

(a)
- Reaction site

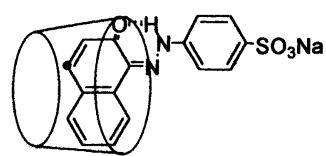

(b)
Fig.2. Inclusion Complexes of 1-arylazo-4-naphthol(a) and 1-arylazo-2-naphthol(b).

substituents on the dyes dramatically change efficiency of retardation by CyD. Though Dye-6 was included in relatively large $K a$ value, no retardation by $\beta$-CyD was observed possibly because inclusion at the naphthol site was rather difficult because of steric inhibition of C-6 sulfo group.

Thus, the rate-retardation efficiency of $\beta-\mathrm{CyD}$ was Dye-3 $>$ Dye-4 $>$ Dye-1 $>$ Dye-2 for 1naphthol-based dyes, and Dye-8 $>$ Dye-5 $>$ Dye$7>$ Dye-6 for 2-naphthol-based dyes. The order shows influence of substituents on naphthol site and other site. Hydrophobic 2'-Me makes retardation more effective, and the $K a$ value larger as anticipated from deep inclusion. Conversely, a hydrophilic and bulky sulfo group at 2'- or 8position inhibits the inclusion to make retardation 
less effective. From these results, the rate-retardation is safely concluded to be caused by disposition of guest in CyD cavity, stability of complex as well as reaction sites.

\section{$3 \cdot 2 \cdot 2 \mathrm{~N}$-addition type}

This reaction starts from the addition of sulfite to $\alpha$-nitrogen of hydrazone tautomer. Therefore, the situation is quite different from the $\mathrm{C}$-addition type. Effects of CyD on the fading of Dye-9-17 are also shown in Table 1 together with the $K a$ values. In particular, the addition of $\alpha$-CyD strongly inhibited the fading for Dye-9-13 bearing a phenyl group at other side, in contrast with fading behavior of the corresponding Dye-1-3, and Dye 57. These striking differences are probably responsible for the shapes of the dye molecules because the molecular structure of 1-arylazonaphthols is L-letter shape, but that of 2-arylazonaphthols is relatively straight line-shape favorable for CyD-complexation. In fact, the CPK modeling of $\alpha$-CyD complexation with the dyes reveals that the aryl site of 1-arylazonaphthols is obliged to be included shallowly in $\alpha$-CyD cavity by steric inhibition due to $\mathrm{C}-8$ and peri- $\mathrm{H}$ at the naphthol site, even if included, but that of 2-arylazonaphthols can be disposed deeply in $\alpha$-CyD cavity. As a result, the azo group (reaction site) of 2-arylazonaphthols attains to the rim of $\alpha$-CyD. Remarkable spectral changes for Dye-9-13 by the addition of $\alpha$-CyD as well as large $K a$ values of these dyes with $\alpha$-CyD reflect the difference in the binding situation for both regioisomers distinctly. Specific fitness of the 2-arylazo-isomers to $\alpha$-CyD cavity must play a definitive role in the striking retardation of the fading reactions starting with the addition of sulfite to $\alpha$-nitrogen of the hydrazone form. On the other hand, $\alpha$-CyD for fading of Dye-14, 15, and 17 bearing two naphthyl residues was always ineffective because of too small diameter of the cavity to include the residue.

In parallel with behavior of $\alpha$-CyD for inclusion of 1 -aryl and 2-arylazonaphthols, $\beta$-CyD also distinguishes between inclusion of both regioisomers, although less distinctive than $\alpha$-CyD. Dye14 and 15, 2-arylazonaphthols, are incorporated into $\beta$-CyD cavity in large $K a$ values to undergo remarkable retardation of the fading. But Dye-16 and 17,1-arylazonaphthols are incorporated into $\mathrm{CyD}$ cavity in small $K a$ values, and consequently the reaction site of the dyes is open to attack of sulfite because of shallow inclusion probably in steric origin.

Substituents on the dyes again influence strongly the retardation of the fading as well as $K a$ values. However, efficiencies of retardation are not proportional to the $K a$ values. This is understandable since the more effective retardation must be caused by the more effective protection of the reaction site due to $\mathrm{CyD}$ inclusions. In other words, when the reaction site is extruded from CyD cavity, the retardation never occurs even when the $K a$ value is large. The typical example is Dye-10 bearing a nitro group. Judging from theoretical and experimental backgrounds ${ }^{18) \sim 20)}$ that the nitrobenzene residue fits to $\mathrm{CyD}$ cavity, the reaction site, instead, seems extruded from CyD cavity. This specificity may be responsible for less efficient retardation despite of the large $\mathrm{Ka}$ value.

\section{Conclusion}

Fading of azo dyes with sodium sulfite retarded by addition of $\alpha$-CyD and $\beta$-CyD through formation of inclusion complexes. $\alpha$-CyD showed higher substrate-selectivity to cause more specific retardation than $\beta$-CyD. The retardation of the fading strongly depended on the reaction site of the dyes in addition to binding constants and disposition of dyes in CyD cavity. Substituents on the dyes controlled the efficiency of retardation. In a sense, fading behavior of the dyes may provide valuable information for disposition of the dyes in CyD cavity at dynamic state, otherwise not easy.

This work was financially supported by Grantin-Aid (B) for Scientific Research from Ministry of Education, Science, Sports and Culture, Japan (No. 09480005).

(Received Nov. 5, 1998 ; Accepted Feb. 10, 1999)

\section{References}

1) F. Toda, A. Ueno, "Cyclodextrin-Kiso to Ouyo", Sangyotosho, Tokyo (1995).

2) F. Cramer, W. Saenger, H.-C. Spatz, J. Am. Chem. Soc., 89, 14 (1967).

3) R.K. McMullan, W. Saenger, J. Fayos, D. Mootz, Carbohydr. Res., 31, 37 (1973).

4) K. Harata, Bull. Chem. Soc. Jpn., 49, 1493 (1976).

5) I. Tabushi, Y. Kiyosuke, T. Sugimoto, K. Yamamura, J. Am. Chem. Soc., 100, 916 (1978). 
6) M. Suzuki, Y. Sawaki, Chem. Pharm. Bull., 27, 609 (1979).

7) M. Suzuki, Y. Sawaki, M. Sugiura, Chem. Pharm. Bull., 27, 1797 (1979).

8) N. Yoshida, M. Fujimoto, Chem. Lett., 1980, 1377.

9) A. Hersey, B.H. Robinson, J. Chem. Soc. Faraday Trans. 1, 80, 2039 (1984).

10) R.J. Clarke, J.H. Coates, S.F. Lincoln, J. Chem. Soc. Faraday Trans.1, 80, 3119 (1984).

11) R.J. Clarke, J.H. Coates, S.F. Lincoln, J. Chem. Soc. Faraday Trans.1, 82, 2333 (1986).

12) Y. Matsui, K. Mochida, Bull. Chem. Soc. Jpn., 51, 673 (1978).

13) K.A. Connors, M.J. Mulski, A. Paulson, J. Org. Chem., 57, 1794 (1992).

14) A. M. Sanchez, R. H. de Rossi, J. Org. Chem., 61,
3446 (1996).

15) K. Seguchi, M. Iwata, S. Tanaka, Sen-I-Gakkaishi, 52, 331 (1996).

16) K. Seguchi, M. Iwata, S. Tanaka, T. Machida, 37 th Synposium on Dyeing Chemistry in Osaka, p.75 (1996) ; J. Soc. Dyers \& Colour., in press.

17) S.R. Sandler, W. Karo, "Organic Functional Group Preparations," Academic Press, New York (1971), p.286.

18) M. Sakurai, M. Kitagawa, H. Hoshi, Y. Inoue, R. Chujo, Chem Lett., 1988, 895.

19) M. Kitagawa, H. Hoshi, M. Sakurai, Y. Inoue, R. Chujo, Bull. Chem. Soc. Jpn., 61, 4225 (1988).

20) C. Katsumata, K. Seguchi, Yukagaku, 45, 857 (1996). 


\title{
[報文]
}

\section{塩化鉄 (III) 一塩化水素錯体を用いた $N-$ クロロアセトアニリド類の Orton 転位}

山本 二郎・多田 宗広・小島 秀和・磯田陽一郎 鳥取大学工学部物質工学科（开680-8552 鳥取市湖山町）

$N$-クロロアセトアニリド (1) を塩化鉄 ( III ) - 塩化水素錯体 $\left(\mathrm{FeCl}_{3}-\mathrm{HCl}\right)$ のエーテル溶液に溶かして室温で放置 すると, 反応は 30 分で完結し， $o^{-}$クロロアセトアニリド (10) とp-クロロアセトアニリド (11) が生成した。オル トーパラ比 $(10 / 11)$ は $\mathrm{FeCl}_{3}-\mathrm{HCl}$ の濃度に依存し, 最高 0.64 に達した。 $N$-クロロ-2-メチルアセトアニリドから は 2 種類の, $N$-クロロ-3-メチルアセトアニリドからは 3 種類の転位生成物がそれぞれ見いだされた。

$N-$ クロロ-2-メチルプロピオンアニリドと $N$-クロロ-2-メチルブチリルアニリドからも, $N-$ クロロ-2-メチル アセトアニリドの場合と同様に，相当するo-および $p$-クロロアニリドが得られ，アシル基が長くなると反応がわ ずかに速くなった。

1 の 3 種類の塩素誘導体はいずれも Orton 転位が起こることなく, 相当するアニリドのみが得られた。メチル 基と塩素をもつ $N$-クロロアセトアニドと $\mathrm{FeCl}_{3}-\mathrm{HCl}$ との反応でも, Orton 転位は進行せず脱塩素反応のみが進 み，それぞれに相当するアセトアニリドが得られた。1 と臭化鉄 (III)-臭化水素錯体 $\left(\mathrm{FeBr}_{3}-\mathrm{HBr}\right)$ との反応から は，好収率で $p$-プロモアセトアニリドが生成した。

$\mathrm{FeCl}_{3}-\mathrm{HCl}$ を用いた 1 の Orton 転位では, パラ位は分子間転位で進行し，オルト位では分子間と分子内との 転位が併発して反応が進行すると考えられる。

(連絡者：山本二郎) Vol. 48, No. 5, 463 (1999)

\section{[報文］亜硫酸ナトリウムによるアゾ染料の退色に 及ぼすシクロデキストリンの効果}

\author{
勝又干寿代・瀬口 和義 \\ 武庫川女子大学生活環境学部（广663-8558 西宮市池開町 6-46）
}

亜硫酸ナトリウムによるアゾ染科 (1-アリルアゾ-2-ナフトール, 1-アリルアゾ-4-ナフトール, 2-アリルアゾ -1-ナフトール) の退色に及ぼすシクロデキストリン $(\mathrm{CyD})$ の効果を $30^{\circ} \mathrm{C} て ゙$ 検討した。染料の退色機構は染料の ヒドラゾン互変異性体の共役エノンに対する亜硫酸の付加 (C-付加), 及び共役イミノンに対する亜硫酸の付加 ( $\mathrm{N}-$ 付加）といった染料の反応部位に応じて 2 種に大別できる。主に1-アリルアゾナフトールでおきる C-付加におい ては, $\beta-\mathrm{CyD}$ の添加により, 染料のナフトール側で包接がおき, 退色が抑制されるのに対し, 空洞の径が小さい $\alpha-\mathrm{CyD}$ の添加では, 退色の抑制は見られなかった。一方, 2-アリルアゾ-1-ナフトールに対しては, $\alpha-\mathrm{CyD}$ は顕 著な退色の抑制効果が見られた。この場合の抑制効果は染料のアリル側で包接がおきることから理解した。また，

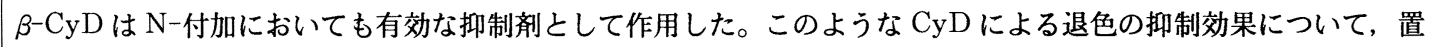
換基効果, $\mathrm{CyD}$ 空洞への染料取り込みの深浅, 染料の反応部位, 結合定数 $(K a)$ から考察した。

（連絡者 : 勝又千寿代）Vol. 48, No. 5, 471 (1999) 